\title{
Green CSR Moderated by Public Visibility and Innovation Performance at Indonesia Companies
}

\author{
Rahmat Hidayat and Farah Margaretha Leon \\ Fakultas Ekonomi dan Bisnis Universitas Trisakti \\ Email: hdrahmat@outlook.com; farahmargaretha@trisakti.ac.id
}

\begin{abstract}
This study aims to analyze the green CSR of innovation performance with firms approval variables and public visibility can support moderating the relationship of green CSR and innovation. The research sample was 33 manufacturing companies. The results showed that the green CSR has a positive and significant effect on innovation . Also, the company approval variable has been proven to moderate the direction of a positive relationship between green CSR and innovation. The results also prove that public visibility is proven to moderate the direction of the negative relationship between green CSR and performance. This study provide information that shows great concern for the environment; it will increase the company in making changes through innovation activities. Also, the higher the company's approval and public visibility, the company will get support from various stakeholders to run the firms. The level of company concern for CSR activities will be a misjudgment for investors.
\end{abstract}

Keywords: innovation performance, green CSR disclosure, company transparency, public visibility.

\begin{abstract}
Abstrak: Penelitian ini bertujuan untuk menganalisis green CSR terhadap inovasi dengan variabel inovasi perusahaan dan visibilitas publik sebagai variabel moderasi yang dapat mendukung hubungan green CSR dan inovasi. Sampel penelitian diperoleh 33 perusahaan manufaktur di BEI. Hasil penelitian menunjukkan bahwa green CSR memiliki pengaruh positif dan signifikan terhadap inovasi. Selain itu, variabel perusahaan terbukti dapat memoderasi dengan arah hubungan positif antara pengungkapan green CSR dan kinerja inovasi. Hasil penelitian juga membuktikan bahwa visibilitas publik terbukti dapat memoderasi dengan arah hubungan negatif antara pengungkapan green CSR dan kinerja. Hasil penelitian ini memberikan informasi yang menunjukkan kepedulian yang tinggi terhadap lingkungan maka akan meningkatkan perusahaan dalam melakukan perubahan melalui kegiatan inovasi. Selain itu, semakin tinggi lingkungan perusahaan dan visibilitas publik, maka perusahaan akan mendapatkan dukungan dari berbagai pemangku kepentingan untuk menjalankan perusahaan. Tingkat kepedulian perusahaan terhadap kegiatan CSR akan menjadi salah pertimbangan investor dalam menanamkan modal.
\end{abstract}

Kata Kunci: kinerja inovasi, pengungkapan csr hijau, transparansi perusahaan, visibilitas publik. 


\section{INTRODUCTION}

The progress of a country is inseparable from economic activities involving many economic actors. One of the economic actors who have a positive contribution to the economic system of a country is the corporation's actor. Every company has an economic goal to make a profit. The company's profit is used as an indicator of the company in fulfilling its obligations to investors, and as one of the factors incorporate value creation in the future. But the company also needs to pay attention to social and environmental aspects to maintain its existence in the business world. Assessment of social and environmental aspects in the company can be described in corporate social responsibility activities or often referred to as Corporate Social Responsibility (CSR).

Corporate Social Responsibility (CSR) describes the multidimensional activities of a company that focuses on various stakeholders, which are outside the interests of the company itself (Rahman and Post, 2012). In implementing CSR activities, the company is required to manage the company strategically to be more concerned about environmental sustainability and social welfare of the community around the company's area (Wu et al., 2018). With the Indonesian government regulation outlined in Law No. 40 of 2007 in article 74 concerning limited liability companies in terms of implementing CSR, currently, CSR practices are starting to develop among companies, both state-owned and private companies.

Green CSR defines the existence of good initiatives from companies on the environment without overriding relevant regulations and laws (Trumpp et al., 2013). Corporate social responsibility has 3 (three) main dimensions, namely earning profit for the company, empowering the social community (people), and preserving the environment (Alhaddi, 2015). The company carries out corporate social responsibility for increasing competitiveness and enables companies to increase competitive advantage by reducing environmental costs (energy efficiency and waste reduction), increasing company marketing (customer recognition and company reputation), and obtaining financial returns return on assets and returns on investment (Ambec et al., 2011). This CSR activity is carried out as a manifestation of the company's management responsibility for the longterm sustainability of the company. Besides, CSR run by the company gets support from stakeholders, where they believe that the company cannot stand alone but depends on various stakeholders to ensure a continuous flow of resources and support (Tantalo and Priem, 2016).

The concept of CSR in maximizing input efficiency and the effectiveness of corporate output is an important reason for companies in creating corporate innovation performance. Environmental problems pose a challenge for companies that prioritize company growth by ignoring excessive resource consumption and environmental degradation. In recent years, there have been changes in stakeholder values from profitoriented to environmentally friendly. Therefore, green CSR is becoming increasingly important to meet these stakeholders, so companies today are often forced to behave more environmentally responsible ( $\mathrm{Wu}$ et al., 2018). Theoretically, CSR practices are a stimulant for companies to develop or adopt new technologies to create favorable conditions for the company (Lioui and Sharma, 2012). Companies with good CSR activities can produce innovation performance in improving the features and quality of the products produced (Grigoriou and Rothaermel, 2017). 
The process of developing corporate innovation performance is certainly inseparable from the active role of stakeholders. Stakeholders argue that the success of a company depends on the ability of the company to involve the desires of other interest groups in the business strategy being run (Bridoux and Stoelhorst, 2014). Various responses from stakeholders on the actions taken by the company are the benchmark of the company in carrying out its business. Public visibility reflects the extent to which stakeholders observe company actions. Public visibility also helps stakeholders to assess whether corporate CSR meets their expectations. Companies with a high level of public visibility can build, maintain, or improve better relations with regulator stakeholders, where it is easier for companies to access preferential financial and political support (Zhao, 2012). Thus the company can increase innovation activities to create new products, new processes, and new ways of operating the company's business.

The process for the creation of innovation performance also requires corporate transparency to build support from stakeholders. Companies with higher levels of transparency provide sufficient information to the public on time and facilitate communication between companies and community stakeholders (Zeng et al., 2012). When corporate transparency is high, information exchange increases effectively, and stakeholders tend to ensure that companies can understand and use information obtained to create more effective innovation performance. Besides, high public transparency indicates that the company has carried out a proactive environmental strategy, which can meet the legal requirements set by regulatory stakeholders/regulators (Cuadrado et al., 2016). The reciprocal relationships of stakeholders built by the high quality of transparency will make the company better known so that the company gets more attention and input from various stakeholders (Wu et al., 2018). Transparency of the company directs stakeholders to interpret and respond positively in the context of information asymmetry, as well as building good interrelations with regulatory stakeholders. Good relations provide benefits for companies to obtain institutional support in the implementation of corporate social responsibility (CSR) activities and produce more efficient and effective innovation activities.

Based on the Euromonitor International report that the manufacturing industry sector has a significant share in the Indonesian economy, where this sector contributes $23.2 \%$ of Gross Domestic Product (GDP) per November 2018 (Raeskyesa, 2019). To maintain the performance of the manufacturing sector, the company is expected to be able to maintain its existence, one of which is through corporate social responsibility activities that are expected to be able to trigger the company's innovation activities. Based on the background explanation above, the researchers wished to conduct a study entitled "The Effect of Green CSR Disclosures Moderated by Public Visibility and Corporate Transparency on Innovation Performance of Manufacturing Company."

\section{THEORETICAL REVIEW}

Innovation Performance. The company's innovation performance in this study focuses on the intensity of research and development or in popular terms, often called Research \& Development ( R \& D) and intangible assets. R \& D is a research and development activity carried out for commercial interests related to research and the applicative development of technology (Trisnajuna and Sisdyani, 2015). The calculation of innovation performance 
can be calculated by dividing total R \& D expenditure by sales (Padgett and Galan, 2016). In this study, green CSR disclosure is thought to affect the intensity of $R \& D$, and this is consistent with the results of the study (Lioui and Sharma, 2012), which revealed that the CSR environment has a positive impact and influence on the intensity of R \& D.

Green Corporate Social Responsibility (CSR). Corporate Social Responsibility (CSR) can be interpreted as a form of social and environmental responsibility from the consequences of company activities through transparency and based on ethical values by allocating attention to sustainable development, health, and social welfare according to stakeholder expectations (Pasaribu, 2015). In this study, CSR is focused on green CSR disclosures. Green CSR defines the existence of good initiatives from the company towards the environment without overriding related regulations and laws (Trumpp et al., 2013). In the implementation of green CSR activities, companies are required to manage the company more strategically so that they have concern for environmental sustainability and the welfare of the community around the company's area (Wu et al., 2018). In this study, the disclosure of green CSR places more emphasis on environmental indicators. Environmental indicators consisting of 17 items of the disclosure can be seen in Appendix 1. In the study of (Lioui and Sharma, 2012), environment CSR is thought to affect the intensity of R \& D. In this study stated the ECSR has a positive impact and influence on the intensity of R \& D.

Corporate Transparency. Corporate transparency makes it easier for stakeholders to obtain company information and can reduce the level of risk caused by information asymmetry (Partha and Noviari, 2016). The amount of transparency of a company can be seen from how complete the information disclosed in the financial statements as well as the annual reports by the management of the company (Pradnyana and Noviari, 2017). Corporate transparency can be measured by summing all items disclosed and divided by the total number of items of voluntary disclosure and timeliness (Ilmiani and Sutrisno, 2014). Disclosure of company transparency is presented in Appendix 2.

Public Visibility. Public visibility reflects the extent to which stakeholders observe company actions. Public visibility also helps stakeholders to assess whether corporate CSR meets their expectations. The research conducted by (Indrawati, 2009) states that political visibility and economic performance have a significant positive effect on CSR disclosure. Public visibility can be measured using a strong advertising intensity. Advertising intensity is calculated by comparing the costs of sales, general, and administration with sales (Wang and Qian, 2011).

Sales Growth. Sales growth can be measured by comparing the percentage change (increase or decrease) in total sales (total sales) on year-end assets against the beginning of the year. The ratio scale is used to measure this variable by changing the calculation results to decimal (Hoque, 2018). The company's growth is one of the elements in the assessment of the company's prospects in the future, and this can be measured through changes in the number of company sales (Deitiana, 2011). Signaling theory shows that if the company's growth is greater, there is a possibility that the company will be able to attract the attention of external parties to invest in the company and facilitate company 
management to obtain loans because of creditor and investor confidence in the company's financial performance (Sawitri and Lestari, 2015). This is also supported by research conducted by (Capasso et al., 2015), which says that sales growth can increase company innovation, especially in $\mathrm{R} \& \mathrm{D}$ activities.

Company Size (Firm Size). The results of (Fachrudin, 2011) state that company size does not influence company performance. This shows that the size of the company is not a guarantee that the company has good performance. Besides, based on research by (Kinanti and Nuzula, 2017), states that companies with a larger scale can operate more efficiently because of the possibility of exploiting economies of scale, having skilled managers, and having good work procedures with the aim that companies have more perform well. Firm size can be calculated using the natural logarithms of the company's total assets (Wu et al., 2018).

Leverage. Leverage can have a positive effect on company performance, and this is the following research conducted by (Fachrudin, 2011), which states that leverage has a positive and significant influence on firm value. Leverage is an external funding source that can be used by companies for investment purposes in the form of asset purchases or others. To determine the company's funding sources, leverage is one option that can be taken as one form of corporate management decisions (Bagus et al., 2016).

Return on Asset (ROA). ROA is a ratio that informs the comparison between earnings (before tax) and average assets (Santoso and Haq, 2017). ROA can be calculated by comparing net income (net profit) and total assets (Suhardjanto and Wardhani, 2010). Return on Assets (ROA) is the ratio of income after interest and tax (earnings after interest and tax) or net income divided by the book value of assets at the beginning of the fiscal year (Wiranata and Nugrahanti, 2013). The greater the value of ROA, then it shows the better performance because it shows the level of return (return) is getting bigger.

Conceptual Framework. The disclosure of green CSR developed by the company is expected to spur innovation performance. Green CSR signifies the company's efforts to accommodate pressure from business stakeholders, which in turn leads to input of knowledge and innovation (Matuszak and Różańska, 2017). The disclosure of green CSR is thought to influence the performance of innovation in the field of $\mathrm{R} \& \mathrm{D}$ with the control variables of sales growth, firm size, leverage, and return on assets. In this study, the effect of green CSR disclosure on innovation performance can be strengthened or weakened by several variables. These variables are corporate transparency and public visibility. Corporate transparency and public visibility act as moderator variables. Corporate transparency and public visibility are thought to be able to strengthen or weaken the effect of green CSR disclosures on the company's innovation performance (Wu et al., 2018). Based on the description that has been described, the conceptual framework can be formed as follows: 
Figure 1. Conceptual Framework

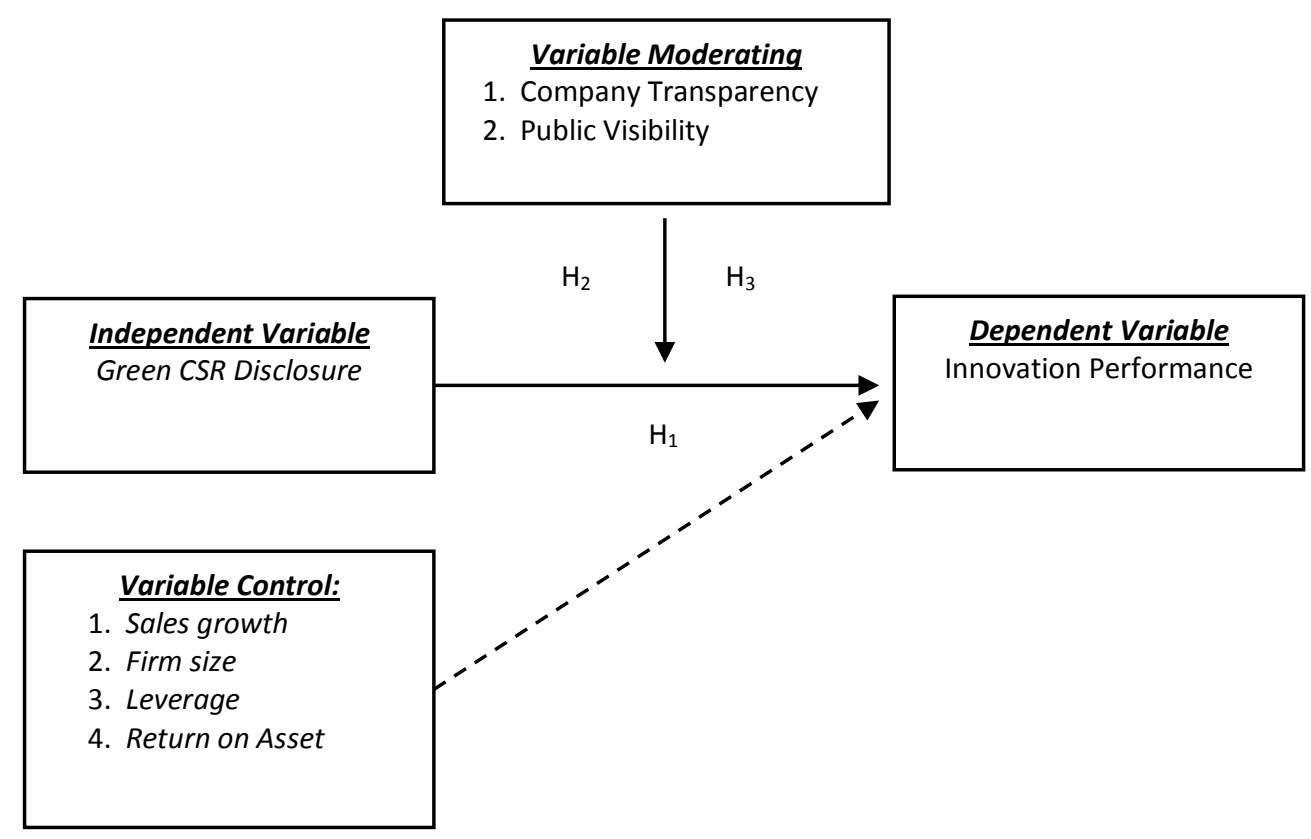

\section{Hypothesis.}

(Wu et al., 2018) revealed in his study that a sustainable approach to the environment was able to foster innovation activities, where the level of company concern for green CSR disclosure influenced by demonstrating improved performance in innovation. (Rexhepi et al., 2013) explained that companies with a stronger disclosure of CSR could lead to innovation through improving product quality features through environmental care activities, which enable company offerings to be unique. Also, (Wei et al., 2015) revealed that the CSR environment signifies the company's efforts to accommodate pressure from business stakeholders, which in turn leads to input of knowledge and triggers innovation. Thus, CSR disclosure initiatives can be the first step in proactive innovation. Based on the results of the above research, the following hypotheses can be formulated:

H1: There is the effect of green CSR disclosure on the company's innovation performance.

Public visibility represents the company's actions observed by stakeholders. The results of the study by (Baldini et al., 2018) show that an increase can influence high corporate visibility incorporate environmental, social disclosures from corporate stakeholders. (Zhao, 2012) research shows that the level of public visibility can build, maintain, and improve good relationships with many stakeholders to facilitate access to financial support. Companies can use this support for innovation activities in creating products and new ways of operating the company. Research Results (Wu et al., 2018) shows that public visibility is significantly and positively correlated with innovation performance. (Servaes and Tamayo, 2013) research reveals that the relationship between CSR disclosure and corporate value is stronger for companies with high levels of public 
awareness, as proxied through advertising expenditure. Based on the results of the above research, the following hypotheses can be formulated:

H2: There is an influence of public visibility on the relationship of green CSR disclosure with the company's innovation performance.

(Vallaster, 2017) revealed in his research that companies that have a high level of corporate transparency in their annual reports are believed to have adopted a more proactive environmental strategy, and facilitating CSR practices and transparency is needed to improve perceptions of trust, credibility, fairness, and satisfaction in all stakeholder networks. With transparency, it is expected that the company will obtain institutional support to produce more efficient and effective innovation processes and activities. (Amores et al., 2014) revealed that the image of a company that carries out social responsibility in the minds of stakeholders could moderate the relationship between environmental product innovation and company performance. The results of research by (Mory et al., 2017) state that $\mathrm{t}$; transparency is very important in companies, especially in the disclosure of CSR reports. The company's transparency in CSR disclosure activities enables the effective exchange of social knowledge that leads to more effective innovations. Based on the results of the above research, the following hypotheses can be formulated:

H3: There is an influence of company transparency on the relationship of green CSR disclosure with the company's innovation performance.

\section{METHODOLOGY}

The data used in this study is panel data. The panel data is a combination of crosssectional and time-series data on industrial and manufacturing sector companies listed on the Indonesia Stock Exchange (IDX) from 2013 through 2017. In this study, it consists of 4 (four) variables namely independent variables or independent variables, dependent variable or dependent variable, moderating variable or intermediate variable, and control variable.

\section{Variables and Measurements}

For simplicity in this study, the following measurements of each variable are as follows:

Dependent Variable. Firm innovation (FINV) or innovation performance in this study focused on the intensity of Research and Development and intangible assets. Measurement of innovation performance according to (Padgett and Galan, 2010); (Kusuma and Bangun, 2011) can be done with the calculation formula as follows:

$$
\text { FINV }=\frac{\text { Total ExpenituresR\&D }+ \text { Intangible Assets }}{\text { Sales }}
$$

Independent Variables. The independent variable of this research is the disclosure of Green Corporate Social Responsibility (CSR) conducted by companies that can be seen from the company's annual report. Variable disclosure of green CSR is measured using 
the CSR reporting index. The following is the formula for calculating the CSR reporting index, according to (Matuszak and Rozanska, 2017):

$$
\text { CSR Reporting index }=\frac{\sum_{i=1}^{n} X_{i}}{n}
$$

Information :

$\mathrm{X}_{\mathrm{i}}: 1$ if the item $\mathrm{i}$ is disclosed, 0 if the item $\mathrm{i}$ is not disclosed,

$\mathrm{N}$ : Number of green CSR disclosure items. 17 CSR green disclosures (disclosures are presented in Appendix 1)

Moderating Variable. Public visibility (PVSB) or public visibility can be measured using strong advertising intensity. Advertising intensity is calculated as the ratio of sales, general, and administrative costs to sales. Following is the calculation formula from PVSB, according to (Wang and Qian, 2011):

$$
\text { PVSB }=\frac{\text { Sales, General, and Adminstrative Costs }}{\text { Sales }}
$$

Company transparency (CTRP) or company transparency can be measured using company reports involving the disclosure of company information. Corporate transparency is measured by proxy voluntary disclosure and timeliness of financial reporting. The proxy can be calculated by summing all items disclosed by the company and divided by the number of all voluntary disclosure items (Ilmiani and Sutrisno, 2014). The formula that can be used according to (Ilmiani and Sutrisno, 2014) is:

$$
\operatorname{CTRP}=\frac{\sum_{i=1}^{n} X_{i}}{n}
$$

Information :

$\mathrm{X}_{\mathrm{i}}: 1$ if the item $\mathrm{i}$ is disclosed, 0 if the item $\mathrm{i}$ is not disclosed

$\mathrm{n}$ : Number of company transparency disclosure items. Disclosure of company transparency consists of 68 disclosures presented in Appendix 2.

Variable Control. Firm size (LNTA) or company size can be calculated using natural logarithms of the company's total assets (Wu et al., 2018).

$$
\text { LNTA }=\text { LN (Total Asset) }
$$

Leverage (LEV) can be calculated using a formula, according to (Huang and Zhu, 2015) as follows:

$$
\text { LEV }=\frac{\text { Total Debt }}{\text { Total Asset }}
$$

Sales Growth (SLGR) can be calculated using the formula, according to (Hoque, 2018) as follows: 


\section{SLGR $=\frac{\text { Present Year Sales- Previous Year Sales }}{\text { Previous Year Sales }}$}

Return on Assets (ROA) can be calculated using the formula according to (Assenga et al., 2018) as follows:

$$
\text { ROA }=\frac{\text { Net income }}{\text { Total Asset }}
$$

The variables and measurements in this study are presented in Table 1.

Table 1. Variables and Measurements

\begin{tabular}{|c|c|c|c|}
\hline No. & Variable & Measurement & References \\
\hline & Dependent Variabl & & \multirow{3}{*}{$\begin{array}{l}\text { (Padgett and Galan, } \\
\text { 2010); (Kusuma and } \\
\text { Bangun, 2011) }\end{array}$} \\
\hline \multirow{3}{*}{1} & Innovation & Total Expenditure R\&D+An intongible Asset & \\
\hline & $\begin{array}{l}\text { Performance } \\
(\text { FINV })\end{array}$ & FWV $=\frac{\text { Soles }}{\text { Sol }}$ & \\
\hline & Independent Varia & & \\
\hline \multirow[t]{2}{*}{2} & $\begin{array}{l}\text { Green CSR } \\
\text { Disclosure (GCSR) }\end{array}$ & $G C S R=\frac{\sum_{i=\mathbb{N}}^{n} X_{i}}{n}$ & $\begin{array}{l}\text { (Matuszak and } \\
\text { Rozanska, 2017) }\end{array}$ \\
\hline & Moderator Variab & & \\
\hline 3 & $\begin{array}{l}\text { Public Visibility } \\
(P V S B)\end{array}$ & PVSB $=\frac{\text { Soles, General, And Adminstrotive Costs }}{\text { Soles }}$ & $\begin{array}{l}\text { (Wang and Qian, } \\
\text { 2011) }\end{array}$ \\
\hline \multirow[t]{2}{*}{4} & $\begin{array}{l}\text { Company's } \\
\text { Transparency } \\
(C T R P)\end{array}$ & $\operatorname{CTRP}=\frac{\sum_{i=\mathbb{I}}^{n} X_{i}}{n}$ & $\begin{array}{l}\text { (Ilmiani and } \\
\text { Sutrisno, 2014) }\end{array}$ \\
\hline & Control Variable & & \\
\hline 5 & Firm Size $(L N T A)$ & LWTA $=$ LN(Totol Asset $)$ & (Wu et al., 2018) \\
\hline 6 & Leverage (LEV) & LEV $=\frac{\text { Total Debt }}{\text { Total Asset }}$ & $\begin{array}{l}\text { (Huang and Zhu, } \\
\text { 2015) }\end{array}$ \\
\hline 7 & $\begin{array}{l}\text { Sales Growth } \\
(\text { SLGR) }\end{array}$ & SLGR $=\frac{\text { Present Year Soles }- \text { Previous Year Soles }}{\text { Previous Yeor Soles }}$ & (Hoque, 2018) \\
\hline 8 & $\begin{array}{l}\text { Return on Asset } \\
(\text { ROA })\end{array}$ & ROA $=\frac{\text { Net income }}{\text { Total Asset }}$ & $\begin{array}{l}\text { (Assenga et al., } \\
\text { 2018) }\end{array}$ \\
\hline
\end{tabular}

Analysis Method. The data analysis method used in this study is the panel data regression method. The panel data model contained in panel data regression, namely common effects, fixed effects, and random effects. The available data is then processed and tested using software e-views 9. The following tests were carried out in this study:

Model Conformity Test. To determine the right and good model to interpret, two stages of testing must be done, namely the chow test and the Hausman test, as follows: 
Chow test. Chow test is used to see which model is more appropriate between common effects and fixed effects. From the test results, if the chosen model is a fixed-effect model, it is necessary to test the fixed effect model with random effects, namely the Hausman test.

Table 2. Chow Test Test Results

\begin{tabular}{ccccc}
\hline Model & Variable & Chi-square & Prob & Decision \\
\hline Model 1 & FINV & 435,6198 & 0,0000 & $\mathrm{H}_{0}$ denied \\
\hline Model 2 & FINV & 437,3874 & 0,0000 & $\mathrm{H}_{0}$ denied \\
\hline Model 3 & FINV & 450,1454 & 0,0000 & $\mathrm{H}_{0}$ denied \\
\hline
\end{tabular}

Source: (Output $e$-views 9, 2019)

Table 2 above shows that the prob value is large. The cross-section of the chi-square model 1 to 3 is 0.0000 smaller than $\alpha=0.05$, then $\mathrm{H} 0$ is rejected, so the model used is the fixed effect model. If the chosen model is a fixed-effect model, it is necessary to test the fixed effect model with a random effect model, namely the Hausman test.

Hausman Test. Two models can be chosen from the results of the Hausman test, namely the fixed effect model with a random effect model. Here are the processed results with eviews nine software from the Hausman test:

Table 3. Hausman Test Test Results

\begin{tabular}{ccccc}
\hline Model & Variable & Chi-square & Prob & Decision \\
\hline Model 1 & FINV & 8,3548 & 0,1377 & $\mathrm{H}_{0}$ accepted \\
\hline Model 2 & FINV & 11,6246 & 0,1136 & $\mathrm{H}_{0}$ accepted \\
\hline Model 3 & FINV & 5,7309 & 0,5715 & $\mathrm{H}_{0}$ accepted \\
\hline
\end{tabular}

Source: (Output e-views 9, 2019)

Table 3 above shows that the prob value. The cross-section of chi-square model 1 is 0.1377 ; model 2 of 0.1136 ; and model 3 is 0.5715 greater than $\alpha=0.05$, then $\mathrm{H} 0$ is accepted. So the model used is a random effect.

Simultaneous Test (Test F). ANOVA test or often known as the F test, basically shows that all the independent variables intended in the model have a simultaneous influence on the dependent variable. The F Test Results are presented in Table 4:

Table 4. F Test Results

\begin{tabular}{cccc}
\hline Model & Variable & Prob & Decision \\
\hline Model 1 & FINV & 0.005460 & $\mathrm{H}_{0}$ denied \\
\hline Model 2 & FINV & 0,000862 & $\mathrm{H}_{0}$ denied \\
\hline Model 3 & FINV & 0,000007 & $\mathrm{H}_{0}$ denied \\
\hline
\end{tabular}

Source: (Output $e$-views 9, 2019) 
Based on Table 4, the results of the regression output of the F probability value of model 1 are 0.005460; model 2 is 0,000862 , and model 3 is 0.000007 smaller than $\alpha=$ 0.05 , then $\mathrm{H}_{0}$ is rejected. This gives the meaning that there is at least one independent variable that influences the dependent variable, so it can be concluded that the regression equation is feasible to use in this study.

Test of Goodness of Fit (adjusted $\mathbf{R}^{\mathbf{2}}$ ). The goodness of fit testing is done to find out how much the independent variable can explain the behavior of the dependent variable. The following is the test results with a test of goodness of fit (adjusted $\mathrm{R}^{2}$ test).

Table 5. The goodness of Fit Test Results

\begin{tabular}{cccc}
\hline Model & Variable & $\mathbf{R}^{\mathbf{2}}$ & Adjusted R $^{\mathbf{2}}$ \\
\hline Model 1 & FINV & 0,097931 & 0,069564 \\
\hline Model 2 & FINV & 0,143425 & 0,105234 \\
\hline Model 3 & FINV & 0,202404 & 0,166842 \\
\hline
\end{tabular}

Source: (Output e-views 9, 2019)

Based on the results of testing table 5, the adjusted $\mathbb{R}^{2}$ value in model 1 is 0.097931 , which means that the variation of the independent variable can explain other factors explain the variation of the dependent variable by $9.79 \%$ and the remaining $90.21 \%$. For model 2 , the adjusted $\mathbb{R}^{2}$ value in model 2 is 0.143425 , which means that the variation of the independent variable can explain other factors explain the variation of the dependent variable by $14.34 \%$ and the remaining $85.66 \%$. As for model 3 , the adjusted $\mathrm{R}^{2}$ value in model 3 is 0.166842 , which means that variations of the independent variables can explain the variation of the dependent variable by $16.68 \%$ and the remaining $83.32 \%$ explained by other factors.

\section{Hypothesis testing}

T-test. The testing of individuals is done to test the regression coefficient by looking at the significance of the influence of each independent variable on the dependent variable by assuming the other variables are constant. Decision criteria are if the sig value is less than $\alpha=0.05$ then Ho is rejected and if the value is sig. More than $\alpha=0.05$, then Ho is accepted.

Multiple Regression Analysis Model. Based on the conceptual framework prepared, to analyze the effect of green CSR, company transparency, public visibility, company size, leverage, return on assets, and sales growth on innovation performance, the equation model is formed as follows:

Model 1:

FINVit $=\alpha+\beta 1$ GCSRit $+\beta 2$ LNTAit $+\beta 5$ LEVit $+\beta 6$ SLGRit $+\beta 7$ ROAit $+\varepsilon$ it

Model 2: 


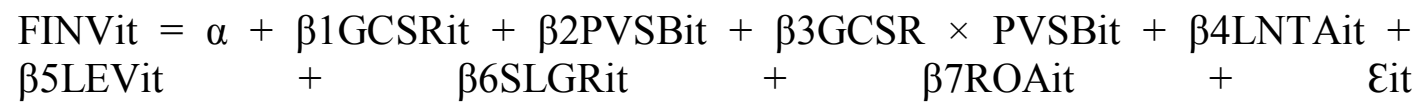

Model 3:

FINVit $=\alpha+\beta 1$ GCSRit $+\beta 2$ CTRPit $+\beta 3$ GCSR $\times$ CTRPit $+\beta$ 4LNTAit + $\beta 5$ LEVit $+\beta 6$ SLGRit $+{ } \quad \beta 7$ ROAit $+{ }$ Eit

\section{RESULTS AND DISCUSSION}

The data used in this study were obtained from financial reports and annual reports for industrial and manufacturing sector companies listed on the IDX during the 2013-2017 period obtained from the official IDX website, www.idx.co.id, and the company's official website. The population of this research is companies that are in the industrial and manufacturing sectors. By using a purposive sampling method, I obtained a sample of 33 companies in the manufacturing sector listed on the Indonesia Stock Exchange (IDX) in 2013-2017 which met certain criteria.

Descriptive statistics are data processing methods used to provide a description or description of a data that is seen from the minimum, maximum, average (mean) and standard deviation. The results of the descriptive statistical analysis are presented in Table 6.

Table 6. Results of Descriptive Statistics Analysis

\begin{tabular}{ccccccc}
\hline No & Variable & N & Mean & Max & Min & $\begin{array}{c}\text { Deviation } \\
\text { Std. }\end{array}$ \\
\hline 1 & LNTA & 165 & 15,3174 & 19,5046 & 11,9801 & 1,611 \\
\hline 2 & LEV & 165 & 0,9795 & 9,4687 & $-8,3383$ & 1,4251 \\
\hline 3 & SLGR & 165 & 9,5427 & 72,0316 & $-24,8262$ & 14,0865 \\
\hline 4 & ROA & 165 & 0,0875 & 0,4018 & $-0,2223$ & 0,1032 \\
\hline 5 & GCSR & 165 & 0,4470 & 0,7647 & 0,0000 & 0,1871 \\
\hline 6 & CTRP & 165 & 0,8047 & 0,9264 & 0,5588 & 0,0803 \\
\hline 7 & PVSB & 165 & 0,0604 & 0,1683 & 0,0090 & 0,0331 \\
\hline 8 & FINV & 165 & 0,0131 & 0,1161 & 0,0000 & 0,0231 \\
\hline Sour & (OUtput & & & & &
\end{tabular}

Source: (Output $e$-views 9, 2019)

Data analysis in this study uses multiple regression tests on panel data with the help of Eviews 9. The following are the results of data analysis:

Effect of Green Corporate Social Responsibility (GCSR) Disclosure on Corporate Innovation Performance. The results of the analysis show that there is a positive and significant influence between the green CSR disclosure variable and the innovation performance variable with a probability value of 0.0004 and a coefficient of 0.0231 . The results of the analysis are presented in Table 7 below. 
Table 7. Model 1 Regression Analysis Results

\begin{tabular}{ccrrrc}
\hline No & Variable & Coefficient & ErrorStd. & Prob. & Note \\
\hline 1 & C & $-0,0226$ & 0,0527 & 0,6688 & - \\
\hline 2 & LNTA & 0,0008 & 0,0018 & 0,6264 & Not significant \\
\hline 3 & LEV & $-0,0002$ & 0,0004 & 0,6444 & Not significant \\
\hline 4 & SLGR & 0,00004 & 0,00004 & 0,2369 & Not significant \\
\hline 5 & ROA & $-0,0088$ & 0,0120 & 0,4631 & Not significant \\
\hline 6 & GCSR & 0,0231 & 0,0063 & 0,0004 & Significant \\
\hline
\end{tabular}

Source: (Output e-views 9, 2019)

The results of this study are following the results of (Rexhepi et al., 2013) research that companies with stronger disclosure of green CSR can lead to innovation through improving product quality features through environmental care activities, which enable the company's offer to be unique. Besides, the results of this study are also following the results of research by (Wu et al., 2018), which shows that there is a significant positive effect between green CSR disclosure and innovation performance. The disclosure of green CSR in this study emphasizes more on corporate activities related to the environment (Wu et al., 2018). The results of this study indicate that the disclosure of green CSR has a positive influence on innovation performance, one of which is the intensity of $R \& D$. This is in accordance with the results of a study by (Lioui and Sharma, 2012) which states that CSR environments have a positive impact and influence on innovation performance, especially the intensity of R \& D. Research and Development can drive the growth of innovation and ultimately create a competitive advantage in the company. Investment in $\mathrm{R}$ \& D can be important information for stakeholders regarding the company's long-term value creation strategy and the management of intellectual capital.

Effect of Public Visibility on the Relationship between Green CSR Disclosure and Corporate Innovation Performance. Public visibility is suspected as a moderator variable that can moderate the effect of green CSR disclosure on innovation performance. Based on the results of the regression test, it was found that public visibility can moderate the direction of the negative relationship between GCSR variables and FINV variables. The results of the analysis are presented in Table 8.

Table 8. Results of Model 2 Regression Analysis

\begin{tabular}{cccccc}
\hline No & Variable & Coefficient & ErrorStd. & Prob. & Note \\
\hline 1 & C & $-0,0276$ & 0,0519 & 0,5954 & - \\
\hline 2 & LNTA & 0,0005 & 0,0017 & 0,7650 & Not significant \\
\hline 3 & LEV & $-0,0001$ & 0,0004 & 0,7429 & Not significant \\
\hline 4 & SLGR & 0,00005 & 0,00004 & 0,1554 & Not significant \\
\hline 5 & ROA & $-0,0104$ & 0,0128 & 0,4198 & Not significant \\
\hline 6 & GCSR & 0,0604 & 0,0141 & 0,0000 & Significant \\
\hline 7 & PVSB & 0,1594 & 0,0742 & 0,0332 & Significant \\
\hline 8 & GCSR $\times$ PVSB & $-0,4274$ & 0,1459 & 0,0039 & Significant \\
\hline
\end{tabular}

Source: (Output $e$-views 9, 2019) 
This is not following the results of the research by (Wu et al., 2018), which shows that the PVSB variable can moderate the direction of a positive relationship between GCSR variables and FINV variables. Also, the results of this study are not following the results of research by (Baldini et al., 2018), which shows that high corporate visibility can influence the increase in environmental, social disclosure of companies from corporate stakeholders. So that in this study it was concluded that public visibility weakened the relationship between green CSR disclosure and innovation performance.

The relationship between green CSR disclosure and company innovation performance is stronger for companies with high levels of public visibility. Visibility levels can usually be proxied through ad spending. These advertisements are used as a medium for disclosing the company's green CSR to increase company value. Companies with good corporate values will maintain their existence through innovation activities for the sustainability of the company in the future (Servaes, 2013).

The Effect of Corporate Transparency on the Relationship between Green CSR Disclosure and Corporate Innovation Performance. The hypothesis test results obtained that corporate transparency can moderate the effect of green CSR disclosures on the company's innovation performance. This can be seen from the probability value of GCSR $\times$ CTRP, which is 0.0313 . The probability value of GCSR $\times$ CTRP is smaller than 0.05 , so that it can be said that corporate transparency can moderate the effect of green CSR disclosure on innovation performance. The results of the analysis are presented in Table 9.

Table 9. Model 3 Regression Analysis Results

\begin{tabular}{ccccc}
\hline Variable & Coefficient & ErrorStd. & Prob. & Note \\
\hline C & $-0,0512$ & 0,0609 & 0,4016 & - \\
\hline LNTA & 0,0030 & 0,0018 & 0,8446 & Not significant \\
\hline LEV & 0,00004 & 0,0004 & 0,9226 & Not significant \\
\hline SLGR & 0,00004 & 0,00003 & 0,2440 & Not significant \\
\hline ROA & $-0,0118$ & 0,0115 & 0,3053 & Not significant \\
\hline GCSR & $-0,1117$ & 0,0580 & 0,0560 & Not significant \\
\hline CTRP & 0,0587 & 0,0430 & 0,1742 & Not significant \\
\hline GCSR $\times$ CTRP & 0,1549 & 0,0713 & 0,0313 & Significant \\
\hline
\end{tabular}

Source: (Output-views 9, 2019)

This is following the results of research by (Wu et al., 2018), which shows that corporate transparency can moderate with the direction of the positive influence between green CSR disclosures on the company's innovation performance. Also, the results of this study are consistent with the research of (Mory et al., 2017), which states that transparency is very important in the company, especially in the disclosure of green CSR reports. The company's transparency in green CSR disclosure activities enables the exchange of effective social knowledge that leads to more effective innovations.

Green Corporate Social Responsibility (CSR) is defined as social and environmental responsibility for the impacts caused by company activities through transparency and based on ethical values by paying attention to sustainable development, health, and social welfare following stakeholder expectations (Pasaribu, 2015). Then it can be said that the 
existence of corporate transparency can increase social and environmental accountability activities to lead to an increase in the company's innovation performance.

\section{Control Variables}

Firm Size (LNTA). Based on Table 7, the results of the analysis show that there is no influence between firm size/size variables on innovation performance variables with a probability value of 0.6264 . The results of this study are not following the results of research by (Kinanti and Nuzula, 2017) which states that larger-scale companies can operate more efficiently due to the possibility of exploiting economies of scale, having skilled managers and having good work procedures with the aim that the company have better performance. The results of (Fachrudin, 2011) state that company size does not influence company performance. This shows that the size of the company is not a guarantee that the company has good performance.

Leverage (LEV). The results of the analysis in Table 7 show a probability value of 0.6444. Based on the probability value, it shows that there is no influence between the leverage variable on the innovation performance variable. The results of this study are not following (Kang and Gray', 2011) research, which shows that leverage significantly influences innovation performance seen from the level of voluntary disclosure of intangible assets.

The results of this study are following the results of research by (Mingfang and Roy , 2002) which states that there is no significant relationship between leverage and innovation performance of the company. The use of the debt portion in terms of funding the company's operational activities does not indicate that the company's performance is also high, especially in terms of innovation activities carried out by the company. Therefore, in this study, the high leverage of the company does not influence the company's innovation activities.

Sales Growth (SLGR). The results of the analysis in Table 7 show that there is no significant effect between the sales growth variable on the innovation performance variable with a probability value of 0.2369 . This is not following the results of the research by (Capasso et al., 2015), which said that sales growth could increase company innovation, especially in $\mathrm{R} \& \mathrm{D}$ activities.

If the sales growth value of a company is high, then it is not certain that the company's innovation performance is also high. The results of this study are consistent with the research conducted by (Coad and Rao, 2007), which states that sales growth has no significant relationship to $\mathrm{R} \& \mathrm{D}$ investment. The large increase in sales of the company is not able to be used as a benchmark in terms of innovation performance. The increase in sales, which is inversely proportional to the amount of net income, does not trigger companies to carry out innovation activities. The company minimizes the cost of operating expenses so that the company's net income can increase.

Return on Asset (ROA). The results of the analysis in Table 7 obtained a probability value of 0.4631 , which means that there is no significant effect between the return on assets variable on the innovation performance variable. This is not following the results of the study of (Wiranata and Nugrahanti, 2013), which states that the greater the value of 
ROA, the better the performance of the company's innovation because it shows a greater return.

Based on the results of the study, if the return on assets of a high company is not necessarily the innovation performance of the company is also high. Return on Assets (ROA) illustrates the extent to which the company's asset capabilities can generate profits. The greater the value of ROA does not always reflect the existence of a relationship with the performance of innovation, where the focus of company management is the maximization of profits on invested capital.

\section{CONCLUSION}

Based on the results of the research that has been done to analyze the effect of green CSR disclosure on the company's innovation performance with the moderator variable of corporate transparency and public visibility as well as company size control variables, sales growth, leverage, and ROA conclusions can be drawn as follows: (1) Disclosure of green CSR has a positive and significant influence on the company's innovation performance. (2) Corporate transparency can moderate the direction of a positive relationship between green CSR disclosure and the company's innovation performance. (3) Public visibility can moderate the direction of the negative relationship between green CSR disclosure and the company's innovation performance. (4) Firm size, leverage, sales growth, and return on assets (ROA) do not influence the company's innovation performance.

Implications. Based on the results of the research that has been done, it is known that the green CSR disclosure variable has an influence on the company's innovation performance, and the company's transparency and public visibility variables are also able to moderate the relationship between green CSR disclosure and the company's innovation performance. So that the managerial implications of this study can provide benefits to several parties as follows:

For Management. To improve innovation performance, companies must be more proactive in responding to various issues related to changes in the company's environment, both internally and externally. To carry out corporate responsibility in terms of the environment, companies must be more innovative both in product development, more effective and efficient work procedures, controlled resource utilization, and the use of appropriate technology. With the deep concern for the environment, the company indirectly takes the initiative to make changes through innovation activities.

Another factor that needs to be considered by companies is company transparency and public visibility. Corporate transparency is the main key for stakeholders to get information related to company activities, both internally and externally. The higher the company's transparency, the company will get support from various stakeholders to carry out the company's innovation activities.

Also, the level of public visibility is one of the supporting factors that need to be considered by the company to inform the company's CSR disclosure activities openly. Public visibility can attract investors and the attention of stakeholders in providing input and advice in the form of knowledge. Visibility is also able to invite other stakeholders to support the company's CSR disclosure activities. This support is a trigger for companies 
to be more innovative because they get more attention from stakeholders. This support is a trigger for companies to carry out innovation activities because they get more attention from stakeholders.

For Investors. The disclosure of green CSR that is supported by the existence of corporate transparency and public visibility can provide investors with an overview of the potential benefits of implementing CSR in terms of company performance. The company's high awareness of the environment also has a positive impact on the progress of the company, where many parties are interested in helping companies to develop innovations for the sustainability of the company. Indicators of company progress are not only seen from the company's ability to generate large profits, but also from the level of company concern for the company's environment both internally and externally. This can also be used as one of the considerations of investors in investing their capital so that the company can continue to develop innovation.

Limitations. Based on the research conducted, this study has several limitations, namely: (1) This study only discusses variables related to company innovation performance, green CSR disclosure, company transparency, public visibility, company size, sales growth, leverage, and return on assets (ROA). (2) Limitations in measuring research variables such as innovation performance, which should utilize information about patents owned by the company. In this study, researchers used information related to the expenditure of R \& D and intangible assets instead of patent data.

Suggestion. From the results of the research and discussion as well as the limitations that have been raised by the researchers, the suggestions that can be recommended for further research are: (1) The next researcher is expected to be able to add or use other independent variables so that other variables are more revealed, which can influence the company's innovation performance such as managerial ownership. (2) Further researchers should be able to use patent data as a manifestation of the innovation performance of companies registered with the Directorate General of Intellectual Property (DJKI).

\section{REFERENCES}

Alhaddi, H. (2015). Triple Bottom Line And Sustainability: A Literature Review. Business And Management Studies, 1(2). https://doi.org/10.11114/bms.v1i2.752.

Ambec, S., Cohen, M. A., Elgie, S., and Lanoie, P. (2011). The Porter Hypothesis At 20 Can Environmental Regulation Enhance Innovation And Competitiveness? The Porter Hypothesis At 20: Can Environmental Regulation Enhance Innovation And Competitiveness?, (January). Retrieved from www.rff.org.

Amores-Salvadó, J., Castro, G. M. De, and Navas-López, J. E. (2014). Green Corporate Image: Moderating The Connection Between Environmental Product Innovation And Firm Performance. Journal Of Cleaner Production, 83, 356-365. https://doi.org/10.1016/j.jclepro.2014.07.059.

Assenga, M. P., Aly, D., and Hussainey, K. (2018). The Impact Of Board Characteristics On The Financial Performance Of Tanzanian Firms. Corporate Governance (Bingley), 18(6), 1089-1106. https://doi.org/10.1108/cg-09-2016-0174. 
Bagus, I. G., Pratama, A., dan Wiksuana, I. G. B. (2016). Pengaruh Ukuran Perusahaan Dan Leverage Terhadap Mediasi Fakultas Ekonomi dan Bisnis Universitas Udayana (Unud), Bali, Indonesia, 5(2), 13381367.https://ojs.unud.ac.id/index.php/Manajemen/article/view/17498.

Baldini, M., Maso, L. D., Liberatore, G., Mazzi, F., and Terzani, S. (2018). Role Of Country- And Firm-Level Determinants In Environmental, Social, and Governance Disclosure. Journal Of Business Ethics, 150(1), 79-98. https://doi.org/10.1007/s10551-016-3139-1.

Bridoux, F., and Stoelhorst, J. W. (2014). Microfoundations For Stakeholder Theory: Managing Stakeholders With Heterogeneous Motives. Strategic Management Journal. https://doi.org/10.1002

Capasso, M., Treibich, T., and. Verspagen, B. (2015). The Medium-Term Effect Of R\&D On Firm Growth. Small Business Economics, 45(1), 39-62. https://doi.org/10.1007/s11187-015-9640-6.

Coad, Alexander; and Rao, Rekha (2007): Firm Growth And R\&D Expenditure, Papers On Economics And Evolution, No. 0710, Max-Planck-Inst. Für Ökonomik, Jena. https://www.econstor.eu/.

Cuadrado-Ballesteros, B., Garcia-Sanchez, I. M., and Martinez Ferrero, J. (2016). How Are Corporate Disclosures Related To The Cost Of Capital? The Fundamental Role Of Information Asymmetry. Management Decision (Vol. 54). https://doi.org/10.1108/md-10-2015-0454.

Deitiana, T. (2011). Pengaruh Rasio Keuangan Pertumbuhan Penjualan Dan Dividend Terhadap Harga Saham. Jurnal Bisnis Dan Akuntansi, 13(1), 57-66. https://doi.org/10.1001/archoto.2008.508.

Fachrudin, K. A. (2011). Analisis Pengaruh Struktur Modal, Ukuran Perusahaan, Dan Agency Cost Terhadap Kinerja Perusahaan. Jurnal Akuntansi Dan Keuangan, 13(1), 37-46. https://doi.org/10.9744/jak.13.1.37-46.

Grigoriou, K., and Rothaermel, F. T. (2017). Organizing For Knowledge Generation: Internal Knowledge Networks And The Contingent Effect Of External Knowledge Sourcing. Strategic Management Journal. https://doi.org/10.1002/smj.2489.

Hoque, A. (2018). Impulse of Dividend Payment Decision: Evidence From Pharmaceutical Industry In Bangladesh. International Journal Of Financial Research, 9(1), 219. https://doi.org/10.5430/ijfr.v9n1p219.

Huang, W., and Zhu, T. (2015). Foreign Institutional Investors And Corporate Governance In Emerging Markets: Evidence Of A Split-Share Structure Reform In China. Journal Of Corporate Finance, 32, 312-326. https://doi.org/10.1016/j.jcorpfin.2014.10.013.

Ilmiani, A., and Sutrisno, C. R. (2014). Pengaruh Tax Avoidance Terhadap Nilai Perusahaan Dengan Transparansi Perusahaan Sebagai Variabel Moderating. Jurnal Ekonomi dan Bisnis. 14, 30-39. https://media.neliti.com/media/publications/5147ID-pengaruh-tax-avoidance-terhadap-nilai-perusahaan-dengan-transparansiperusahaan.pdf.

Indrawati, N. (2009). Pengungkapan Corporate Social Responsibility (CSR) Dalam Annual Report Serta Pengaruhnya Terhadap Political Visibility Dan Economic Performance. Pekbis Jurnal, 1(1), 1-11. https://media.neliti.com/media/publications/8924-ID-pengungkapan-corporate- 
social-responsibility-csr-dalam-annual-report-serta-penga.pdf.

Kang, H. H., and Gray, S. J. (2011). Reporting Intangible Assets: Voluntary Disclosure Practices Of Top Emerging Market Companies. International Journal of Accounting, 46(4), 402-423. https://doi.org/10.1016/j.intacc.2011.09.007.

Kinanti, dan Nuzula. (2017). Pengaruh Intensitas R\&D Terhadap Nilai Perusahaan Dengan Variabel Kontrol Umur Dan Ukuran Perusahaan (Studi Pada Perusahaan Manufaktur Yang Tercatat Di Bursa Efek Indonesia Periode 2012-2016), 60(2), 3847. http://administrasibisnis.studentjournal.ub.ac.id/.

Kusuma, B. H., dan Bangun, Nuraini. (2011). Analisis Pemahaman Mahasiswa Akuntansi Terhadap Konsep Aset, Kewajiban, dan Ekuitas. Jurnal Bisnis dan Akuntansi, Vol. 13, No.3.183-194. http://jurnaltsm.id/index.php/JBA/article.

Lioui, A., and Sharma, Z. (2012). Environmental Corporate Social Responsibility And Financial Performance: Disentangling Direct And Indirect Effects. Ecological Economics, 78, 100-111. https://doi.org/10.1016/j.ecolecon.2012.04.004.

Matuszak, Ł., and Różańska, E. (2017). An Examination Of The Relationship Between Csr Disclosure And Financial Performance: The Case Of Polish Banks. Accounting And Management Information Systems, 16(4), 522-533. https://doi.org/10.24818/jamis.2017.04005.

Mingfang, L., and Roy, S. (2002). Environmental Dynamism, Capital Structure And Innovation: An Empirical Test. The International Journal Of Organizational Analysis. https://doi.org/http://dx.doi.org/.

Mory, L., Wirtz, B. W., and Göttel, V. (2017). Corporate Social Responsibility: The Organizational View. Journal Of Management And Governance, 21(1), 145-179. https://doi.org/10.1007/s10997-015-9337-x.

Padgett, R. C., and Galan, J. I. (2016). On Corporate Of R \& D Intensity The Effect Social Responsibility, 93(3), 407-418. https://onlinelibrary.wiley.com/doi/abs/10.1002/csr.1335

Partha, I. G. A., and Noviari, N. (2016). Pengaruh Penghindaran Pajak Jangka Panjang Pada Nilai Perusahaan Dengan Transparansi Informasi Sebagai Variabel Pemoderasi, 3, 2336-2362. http://e-journal.uajy.ac.id/13394/1/JURNAL.pdf.

Pasaribu, Kowanda, K. (2015). Jurnal Riset Manajemen Dan Bisnis. Jurnal Riset Manajemen \& Bisnis, 10(2), 97-121.

https://www.researchgate.net/profile/rowland_pasaribu/publication/290821310.

Pradnyana, I. B. G. P., and Noviari, N. (2017). Pengaruh Perencanaan Pajak Terhadap Nilai Perusahaan Dengan Transparansi Perusahaan Sebagai Variabel Moderasi. EJurnal Akuntansi Universitas Udayana. https://ojs.unud.ac.id/index.php/Akuntansi/article/view/25707.

Raeskyesa, D.G.S. (2019). Melongok Peran Manufaktur. http://www.koranjakarta.com/melongok-peran-manufaktur/.

Rahman, N., and Post, C. (2012). Measurement Issues In Environmental Corporate Social Responsibility (CSR): Toward A Transparent, Reliable, And Construct Valid Instrument. Journal Of Business Ethics, 105(3), 307-319. https://doi.org/10.1007/s10551-011-0967-x.

Rexhepi, G., Kurtishi, S., and Bexheti, G. (2013). Corporate Social Responsibility (CSR) And Innovation-The Drivers Of Business Growth? Procedia - Social And Behavioral Sciences, 75, 532-541. https://doi.org/10.1016/j.jnoncrysol.2011.07.002. 
Santoso dan Haq. (2017). Analisis Determinan Pengungkapan Islamic Social Reporting: Studi Kasus Bank Umum Syariah di Indonesia. Jurnal Ekonomi Syariah, 2(1), 95115. https://doi.org/10.1017/cbo9781107415324.004.

Sawitri, N. P. Y. R. dan Lestari, V. P. (2015). Pertumbuhan Penjualan Terhadap Struktur Modal. E-Jurnal Manajemen Unud, 4(5), 1238-1251. https://simdos.unud.ac.id/uploads/file_penelitian_1_dir/.

Servaes, H., and Tamayo, A. (2013). The Impact of Corporate Social Responsibility on Firm Value: The Role of Customer Awareness, 59(5), 1045-1061. Journal Management Science. https://doi.org/10.1287/mnsc.1120.1630.

Suhardjanto, D., and Wardhani, M. (2010). Praktik Intellectual Capital Disclosure Perusahaan. JAAI, 14(1), 71-85. https://journal.uii.ac.id/JAAI/article/view.

Tantalo, C., and Priem, R. L. (2016). Value Creation Through Stakeholder Synergy. Strategic Management Journal. https://doi.org/10.1002/smj. 2337.

Trisnajuna, M., dan Sisdyani, E. A. (2015a). Pengaruh Aset Tidak Berwujud Dan Biaya Penelitian Dan Pengembangan Terhadap Nilai Pasar Dan Kinerja Keuangan Perusahaan. Jurnal Akuntansi Universitas Udayana Desember. https://ojs.unud.ac.id/index.php/Akuntansi/article/view/14409.

Trumpp, C., Endrikat, J., Zopf, C., and Guenther, E. (2013). Definition, Conceptualization, And Measurement Of Corporate Environmental Performance: A Critical Examination Of A Multidimensional Construct. Journal Of Business Ethics, 126(2), 185-204. https://doi.org/10.1007/s10551-013-1931-8.

Vallaster, C. (2017). Managing A Company Crisis Through Strategic Corporate Social Responsibility: A Practice-Based Analysis. Corporate Social Responsibility And Environmental Management, 24(6), 509-523. https://doi.org/10.1002/csr.1424.

Wang, H., and Qian, C. (2011). Corporate Philanthropy And Corporate Financial Performance: The Roles Of Stakeholder Response And Political Access. Academy Of Management Journal, 54(6), 1159-1181. https://doi.org/10.5465/amj.2009.0548.

Wei, Z., Shen, H., Zhou, K. Z., and Li, J. J. (2015). How Does Environmental Corporate Social Responsibility Matter In A Dysfunctional Institutional Environment? Evidence From China. Journal Of Business Ethics, 140(2), 209-223. https://doi.org/10.1007/s10551-015-2704-3.

Wiranata, Y. A., dan Nugrahanti, Y. W. (2013). Pengaruh Struktur Kepemilikan Terhadap Profitabilitas Perusahaan Manufaktur Di Indonesia. Jurnal Akuntansi Dan Keuangan, 15(1), 15-26. https://doi.org/10.9744/jak.15.1.15-26.

Wu, W., Liu, Y., Chin, T., and Zhu, W. (2018). Will Green Csr Enhance Innovation? A Perspective Of Public Visibility And Firm Transparency. International Journal of Environmental Research And Public Health, 15(2), 1-14. https://doi.org/10.3390/ijerph15020268.

Zeng, S. X., Xu, X. D., Yin, H. T., and Tam, C. M. (2012). Factors That Drive Chinese Listed Companies In Voluntary Disclosure Of Environmental Information. Journal Of Business Ethics, 109(3), 309-321. https://doi.org/10.1007/s10551-011-1129-x.

Zhao, M. (2012). Csr-Based Political Legitimacy Strategy: Managing The State By Doing Good In China And Russia. Journal Of Business Ethics, 111(4), 439-460. https://doi.org/10.1007/s10551-012-1209-6.

Website Bursa Efek Indonesia (www.idx.co.id) 